$\mathrm{DE}$

M E D I C I N A

T R O P I C A L

$\mathrm{DE}$

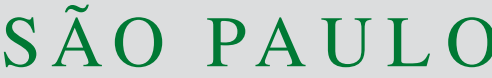

JOURNAL OF THE SÃO PAULO INSTITUTE OF TROPICAL MEDICINE

${ }^{1}$ Universidade Federal do Rio de Janeiro, Instituto de Puericultura e Pediatria Martagão Gesteira, Rio de Janeiro, Rio de Janeiro, Brazil

${ }^{2}$ Universidade Federal do Rio de Janeiro, Faculdade de Medicina, Departamento de Pediatria, Rio de Janeiro, Rio de Janeiro, Brazil

${ }^{3}$ Universidade Federal do Rio de Janeiro, Instituto de Doenças do Tórax, Rio de Janeiro, Rio de Janeiro, Brazil

${ }^{4}$ Universidade Federal do Rio de Janeiro, Faculdade de Medicina, Instituto de Doenças do Tórax, Programa Acadêmico de Tuberculose, Rio de Janeiro, Rio de Janeiro, Brazil

Correspondence to: Rafaela Baroni Aurilio Universidade Federal do Rio de Janeiro, Instituto de Pediatria e Puericultura Martagão Gesteira, R. Bruno Lobo 50, CEP 21941-912, Rio de Janeiro, RJ, Brazil Tel: +55 21 3938-4811

E-mail: rafabaroni@yahoo.com.br

Received: 13 September 2021

Accepted: 10 January 2022

\section{Gene-Xpert Ultra for the diagnosis of extrapulmonary tuberculosis in children and adolescents}

\author{
Rafaela Baroni Aurilio ${ }^{1}$, Sidnei Ferreira², Ana Alice Amaral lbiapina Parente ${ }^{2}$, \\ Maria de Fátima Pombo Sant'Anna², Cláudia Stella Pereira', Thiago da Silva \\ Santos Malaquias ${ }^{3}$, Afrânio Lineu Kritski ${ }^{4}$, Clemax Couto Sant’Anna ${ }^{\circledR}$
}

\section{ABSTRACT}

This prospective study describes the use of Gene-Xpert Ultra for the diagnosis of extrapulmonary tuberculosis (EPTB) in children and adolescents, in Rio de Janeiro, Brazil. Eighteen patients were studied; the final diagnosis of EPTB was established in 13 (72\%). Gene-Xpert Ultra results showed detection in 10/13 (77\%) of EPTB cases (7 of these 10 with trace-positive results). Gene-Xpert Ultra proved to be a promising method for the diagnosis of childhood EPTB.

KEYWORDS: Extrapulmonary tuberculosis. Children. Adolescents. Diagnoses. Real-time PCR.

\section{INTRODUCTION}

In 2017, the World Health Organization (WHO) endorsed the replacement of Gene-Xpert MTB RIF (Xpert) with Gene-Xpert Ultra (Ultra). When compared to Xpert, Ultra showed a lower detection limit of Mycobacteruim tuberculosis (M. tb.) from 116 (with Xpert) to 15.6 CFU. Ultra maintains the real-time PCR technique, with the addition of two more $M$. $t b$. targets and changes in the melting curve, favoring the detection of rifampicin (RMP) resistance. Detection of bacillary load is categorized as high, medium, low, and trace-positive results. The latter category indicates that the ISI081 and IS6110 M. tb. targets were detected, but not in the specific region of TB rpo- $\beta$ gene, resulting in an indeterminate resistance to RMP. Hence, there is a greater sensitivity of Ultra compared to Xpert ${ }^{1,2}$. In Brazil, Ultra was incorporated in December 2019 for the diagnosis in children younger than 10 years old. In extrapulmonary TB (EPTB), trace-positive results indicate positivity to $M . t b{ }^{3}$. To date, we have not identified studies in the literature that used Ultra exclusively for the diagnosis of EPTB in children ${ }^{4}$. The current prospective preliminary study aims at describing the use of Ultra in a reference university hospital for pediatric TB, from April 2020 to February 2021, in Rio de Janeiro, Brazil.

\section{MATERIALS AND METHODS}

The study included children (<10 years old) and adolescents (ages $10-19$ years) consecutively enrolled with presumed TB whose specimens were submitted to GeneXpert Ultra. This study has been approved by the IPPMG-UFRJ Ethics Committee (CAAE 02173518.2.0000.5264). After written informed consent was obtained from participant's parents or caregivers, the sample was collected and submitted 
to Ultra analyses. Variables studied were: age, exposure to TB in the last two years, positive tuberculin skin test (TST) results (positive $\geq 5 \mathrm{~mm}$; negative $<5 \mathrm{~mm}$ ], Ultra results (detected, trace, and undetected), acid-fast bacilli test results (positive and negative) and culture for $M$. $t b$ by the Mycobacterial Growth Indicator Tube (MGIT 960) method (positive, negative and inconclusive due to contamination). In the latter, when the result is positive, an antimicrobial sensitivity test (AST) was performed. The final diagnosis of EPTB was established by laboratory confirmation (using Ultra), clinical data and a favorable clinical response after 60 days of treatment.

\section{RESULTS AND DISCUSSION}

From a total of 23 patients initially included in the study, $18(78 \%)$ were children and $5(22 \%)$ were adolescents. Ages ranged from 11 months to 12 years. Of all patients, $18(78 \%)$ were presumed to have EPTB and 5 (22\%) were presumed to have pulmonary tuberculosis (PTB). The description of the Ultra results according to TB forms is shown in Figure 1.

The final diagnosis of PTB was established in four out of five patients $(80 \%)$, in whom $2 / 4(50 \%)$ were children and $2 / 4(50 \%)$ were adolescents; Ultra results were tracepositive in all four cases of PTB and all corresponding cultures were negative.

The final diagnosis of EPTB was established in 13 out of 18 patients $(72 \%)$, and five patients $(28 \%)$ received other diagnoses; Ultra detected 10 of 13 (7/10 were trace-positive) and culture was positive in only 3 of these 10 positive patients by Ultra. Six of the 13 patients (46\%) presented with peripheral enlarged lymph node TB, three (23\%) pleural, and four (31\%) had other manifestations (one peritoneal, one bone, one sacroiliac and one soft tissue swelling over the sternum). There were no cases of resistance to RMP by Ultra or AST. All patients with Ultra trace-positive results or not detected results had a negative culture, as shown in Table 1.

The positivity of Ultra (detected or trace-positive) in the present study occurred in $77 \%$ of EPTB patients. Unlike the latest WHO Manual, these results endorse the recommendation of the Ministry of Health in Brazil in which trace-positive results are considered to point to $M$. $t b$. positivity in a paucibacillary sample (pediatric and extrapulmonary sample) $)^{3,4}$. Ultra detected $67 \%(4 / 6)$ of the patients with enlarged lymph node TB. This percentage is a little higher than in a previous study $(56 \% ; 5 / 9)$ carried out in our hospital, although the lymph node TB samples were small in both studies $^{5}$. This finding corroborates the Ultra's superiority over Xpert in the diagnosis of paucibacillary forms of TB.

Ultra has also contributed to the diagnosis of pleural TB in our study. Conversely, in a study in Shanghai (China) with patients over 16 years old, the positivity of Ultra in tissue aspirates (lymph node, thoracic or abdominal wall, skin, crissum and bone) was higher (79\%) than that of pleural fluid samples $(43.7 \%)$, probably because the bacillary load in tissues or abscesses is greater than in serous liquids; 23 of the 30 patients showed trace-positive results in Ultra with concomitant negative cultures ${ }^{6}$. Our patients with trace-positive results presented negative cultures as well, perhaps due to the very low bacillary load detected by Ultra.

In patients of different ages and in different clinical specimens, Ultra sensitivities ranged from 90 to $95 \%$, and specificities ranged from 86 to $99 \%^{7-9}$. We did not perform a comparison between Xpert and Ultra, as Xpert is no longer available in Brazil.

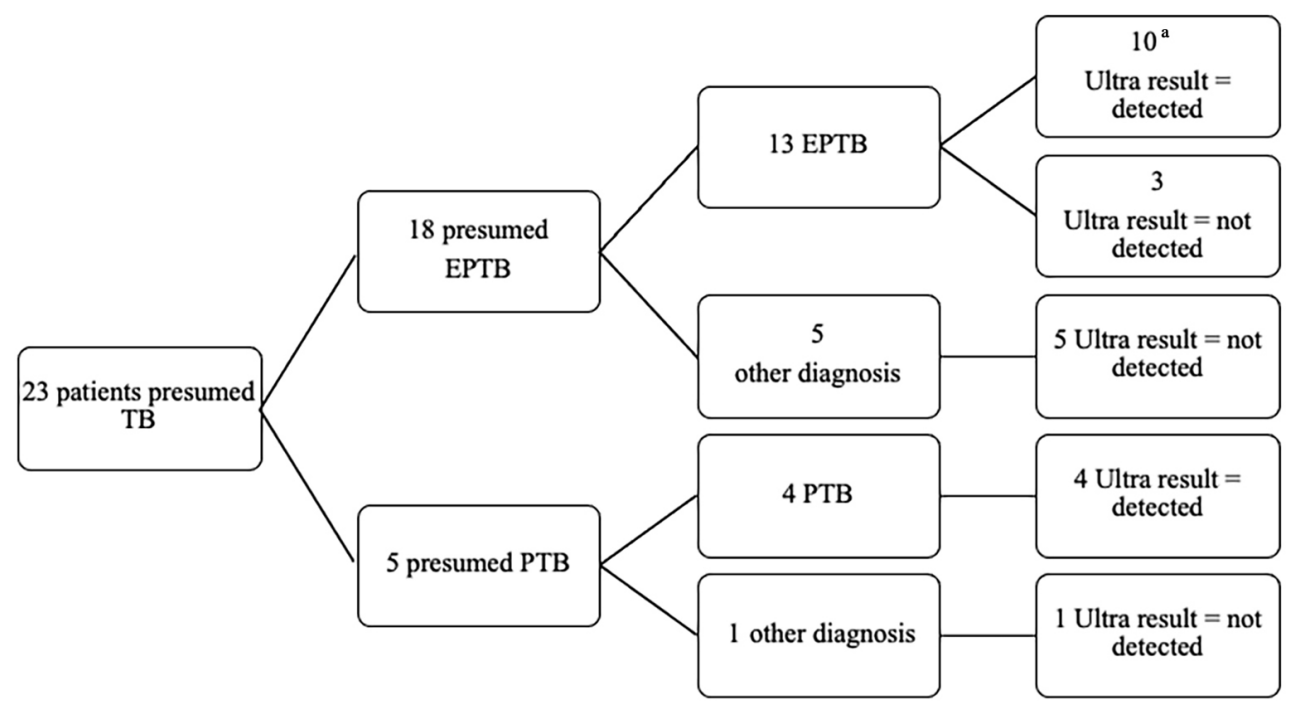

Figure 1 - Description of the Ultra results according to the final diagnosis. ${ }^{a} 7 / 10=$ trace-positive results; TB = tuberculosis; $\mathrm{ETBP}=$ extrapulmonary tuberculosis; TBP = pulmonary tuberculosis. 
Table 1 - Description of patients with a final diagnosis of extrapulmonary tuberculosis $(n=13)$.

\begin{tabular}{|c|c|c|c|c|c|c|c|c|c|}
\hline $\begin{array}{l}\text { Patient } \\
\text { number }\end{array}$ & $\begin{array}{c}\text { Age } \\
\text { (years) }\end{array}$ & $\begin{array}{c}\text { Close } \\
\text { contact } \\
\text { with TB }\end{array}$ & TST & Sample & Ultra result & $\begin{array}{l}\mathrm{RMP}- \\
\text { resistance }\end{array}$ & AFB & Culture & Final diagnoses \\
\hline 1 & 0.9 & Yes & Positive & Lymph node I & Not detected & No & Negative & Negative & $\begin{array}{c}\text { Peripheral lymph } \\
\text { node TB }\end{array}$ \\
\hline 2 & 1.5 & No & $\begin{array}{c}\text { Not } \\
\text { performed }\end{array}$ & Lymph node & Detected & No & Negative & Positive $^{a}$ & $\begin{array}{c}\text { Peripheral lymph } \\
\text { node TB }\end{array}$ \\
\hline 3 & 2 & No & Positive & $\begin{array}{l}\text { Soft tissue } \\
\text { swelling } \\
\text { over the } \\
\text { sternum }\end{array}$ & Detected & No & Negative & Positive $^{a}$ & $\begin{array}{c}\text { Bone TB + } \\
\text { Pulmonary TB }\end{array}$ \\
\hline 4 & 2.1 & Yes & Positive & Lymph node & $\begin{array}{l}\text { Trace- } \\
\text { positive }\end{array}$ & Indeterminate & Negative & Negative & $\begin{array}{c}\text { Peripheral lymph } \\
\text { node TB }\end{array}$ \\
\hline 5 & 6.5 & No & Negative & Lymph node & $\begin{array}{l}\text { Trace- } \\
\text { positive }\end{array}$ & Indeterminate & Negative & Negative & $\begin{array}{c}\text { Peripheral lymph } \\
\text { node TB }\end{array}$ \\
\hline 6 & 8.5 & No & Negative & $\begin{array}{l}\text { Pleural } \\
\text { effusion }\end{array}$ & $\begin{array}{l}\text { Trace- } \\
\text { positive }\end{array}$ & Indeterminate & Negative & Negative & Pleural TB \\
\hline 7 & 8.9 & No & Positive & Lymph node & Detected & No & Negative & Positive $^{a}$ & $\begin{array}{c}\text { Peripheral lymph } \\
\text { node TB }\end{array}$ \\
\hline 8 & 10 & WI & Negative & $\begin{array}{l}\text { Peritoneal } \\
\text { fluid }\end{array}$ & $\begin{array}{c}\text { Trace- } \\
\text { positive }\end{array}$ & No & Negative & Negative & Peritoneal TB \\
\hline 9 & 10.5 & No & Negative & Bone & $\begin{array}{l}\text { Trace- } \\
\text { positive }\end{array}$ & Indeterminate & Negative & Negative & $\begin{array}{c}\text { Osteoarticular } \\
\text { TB }\end{array}$ \\
\hline 10 & 10.9 & No & Positive & $\begin{array}{l}\text { Pleural } \\
\text { effusion }\end{array}$ & $\begin{array}{l}\text { Trace- } \\
\text { positive }\end{array}$ & Indeterminate & Negative & Negative & Pleural TB \\
\hline 11 & 11.2 & No & Negative & $\begin{array}{l}\text { Sacroiliac } \\
\text { abscess }\end{array}$ & $\begin{array}{l}\text { Trace- } \\
\text { positive }\end{array}$ & Indeterminate & Negative & Negative & $\begin{array}{c}\text { Osteoarticular } \\
\text { TB + Pulmonary } \\
\text { TB }\end{array}$ \\
\hline 12 & 11.3 & No & Positive & Lymph node I & Not detected & No & Negative & Negative & $\begin{array}{c}\text { Peripheral lymph } \\
\text { node } \text { TB }^{\mathrm{b}}\end{array}$ \\
\hline 13 & 11.5 & Yes & Positive & Pleura & Not detected & No & Negative & Negative & Pleural TB $^{c}$ \\
\hline
\end{tabular}

$\mathrm{WI}=$ without information; TST = Tuberculin skin test; a Sensitive to first-line drugs; EPTB = extrapulmonary tuberculosis; ${ }^{\mathrm{b}}$ Diagnosis made by histopathological exams compatible with TB; ' Diagnosis based on clinical history and TST result.

Among the limitations of this study, we acknowledge that the small number of patients with EPTB could have acted as a selection bias in the results and the collection of only one sample per patient may have reduced the positivity of Ultra which, regardless, was high. As the study was carried out in a reference center for TB, patients of greater complexity and with a greater pretest probability for active TB may have been selected.

Ultra proved to be a promising method in the diagnosis of EPTB in children, but we emphasize that negative results do not exclude the diagnosis ${ }^{3,4}$. Studies with a larger pediatric population are necessary, before it can be inferred that Ultra should be used in clinical practice.

\section{CONFLICT OF INTERESTS}

The authors declare that there are no conflict of interests.

\section{FUNDING}

This study was supported by the Brazilian Council for Research and Technological Development (Conselho Nacional de Desenvolvimento Científico e Tecnológico - CNPq), grant $N^{\circ} 302973 / 2019-2$ to CCSA, and CNPq/ INCT grant $\mathrm{N}^{\circ} 421703 / 2017-2$ to ALK.

\section{REFERENCES}

1. Opota O, Mazza-Stalder J, Greube G, Jaton K. The rapid molecular test Xpert MTB/RIF ultra: towards improved tuberculosis diagnosis and rifampicin resistance detection. Clin Microbiol Infect. 2019;25:1370-6.

2. Chakravorty S, Simmons AM, Rowneki M, ParmarH, Cao Y, Ryan J, et al. The new Xpert MTB/RIF Ultra: improving detection of Mycobacterium tuberculosis and resistance to rifampin in an assay suitable for point-of-care testing. mBio. 2017;8:e00812-17. 
3. Brazil. Ministério da Saúde. Secretaria de Vigilância em Saúde. Departamento de Doenças de Condições Crônicas e Infecções Sexualmente Transmissíveis. Coordenação-Geral de Vigilância das Doenças de Transmissão Respiratória de Condições Crônicas. Revogação da Nota Técnica No 22/2018-CGPNCT/ DEVIT/MS sobre a indisponibilidade temporária da rifampicina 300mg cápsula e rifampicina suspensão oral 20mg/ $\mathrm{ml}$ para o tratamento da infecção latente pelo Mycobacterium tuberculosis. [cited 2022 Jan 10]. Available from: https:// central3.to.gov.br/arquivo/472141/

4. World Health Organization. WHO consolidated guidelines on tuberculosis. Module 3: diagnosis - rapid diagnostics for tuberculosis detection, 2021 update. Geneva: WHO; 2021. [cited 2022 Jan 10]. Available from: https://www.who.int/ publications/i/item/9789240029415

5. Aurilio RB, Marsili VV, Malaquias TS, Kritski AL, Sant'Anna CC. The use of Gene-Xpert MTB RIF in the diagnosis of extrapulmonary tuberculosis in childhood and adolescence. Rev Soc Bras Med Trop. 2020;53:e20200104.
6. Wu Xi, Tan G, Gao R ,Yao L ,Bi D ,Guo Yet al. Assessment of the Xpert MTB/RIF Ultra assay on rapid diagnosis of extrapulmonary tuberculosis. Int J Infect Dis 2019;81:91-6.

7. Hoel IM, Syre H, Skarstein I,Mustafa T. Xpert MtB/Rif ultra for rapid diagnosis of extrapulmonary tuberculosis in a high-income low-tuberculosis prevalence setting. Sci Rep. 2020;10:13959.

8. Mekkaoui L, Hallin M, Mouchet F, Payen M, Maillart E, Clevenbergh P, et al. Performance of Xpert MTB/RIF Ultra for diagnosis of pulmonary and extra-pulmonary tuberculosis, one year of use in a multi-centric hospital laboratory in Brussels, Belgium. PLoS One. 2021;16:e0249734.

9. Piersimoni C, Gherardi G, Gracciotti N, Pocognoli A. Comparative evaluation of Xpert MTB/RIF and the new Xpert MTB/RIF ultra with respiratory and extra-pulmonary specimens for tuberculosis case detection in a low incidence setting. J Clin Tuberc Other Mycobact Dis. 2019;15:100094. 